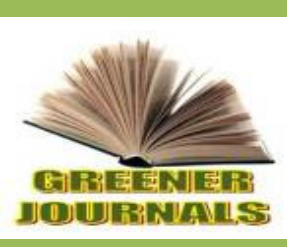

\title{
Comparative Study of Amino Acid Profile of Urea Plus Methionine Supplemented and Fermented Sorghum Beer Residue with that of other Protein Standards
}

\section{*Ndams SS, Alli-Balogun JK, Mohammed A, Shuaibu SA and Osagiede NO}

College of Agriculture and Animal Science, Ahmadu Bello University, Mando Rd. Kaduna. Nigeria.

ARTICLE INFO

Article No.: 022616044

DOI: 10.15580/GJAS.2016.3.022616044

Submitted: $26 / 02 / 2016$

Accepted: 07/02/2016

Published: 28/03/2016

*Corresponding Author

Ndams SS

E-mail: Samuel_ndams@yahoo. com

Phone: +2348086183938

Keywords:

Sorghum beer residue, Urea, Methionine, Fermentation and Amino acid
Sorghum beer residue (SBR), a by-product of local brewery was purchased dried, supplemented with urea and methionine at concentrations ratio of $1.5: 0.37 \%$. It was inoculated with rumen liquor of cow and subjected to four days fermentation in a $5 \mathrm{ft}$ deep pit. After 4days fermentation, the urea plus methionine supplemented and fermented sorghum beer residue (RSBR) was sundried for 7days on concrete floor and samples taken for the determination of amino acid composition. The amino acid profile of RSBR sample revealed the availability of all essential amino acids except tryptophan (alanine, arginine, glycine, histidine, isoleucine, leucine, lysine, methionine, phenylalanine, threonine and valine) in the sample. The amino acid profile of RSBR were higher than those of SBR, Groundnut cake (GNC), Soya bean cake (SBC), Food and Agricultural Organization (FAO) and other Animal Feed Standards (AFS). The superiority of essential amino acids in RSBR sample is an indication that it can serve as protein sources in place of conventional plant protein sources. 


\section{ABBREVIATIONS}

1. $\quad \mathrm{SBR}=$ Sorghum beerresidue

2. RSBR $=$ Re-fermented sorghum beerresidue

3. $\mathrm{GNC}=$ Groundnutcake

4. $\quad \mathrm{SBC}=$ Soya bean cake

5. $\quad \mathrm{FAO}=$ Food and AgriculturalOrganization

6. $\quad \mathrm{AFS}=$ Animal FeedStandard

\section{INTRODUCTION}

In Nigeria today, more than $50 \%$ of the country's poultry farms have closed down and another $30 \%$ forced to reduce their production capacity because of shortage of feed (Esonu el at., 2001). This feed shortage has been blamed on high cost of the conventional sources of feed ingredients which was rated by Madubuike and Ekenyem, 2006 at $70-80 \%$ of total cost of poultry production. Soya bean and groundnut cakes have been used as protein supplements in poultry diets but their high cost has engineered the need to look for locally available and cheap sources of feed ingredients particularly those that do not attract competition between humans and livestock and for which Pousgha et al ., 2007 suggested traditional Sorghum beer residue. The nutritional qualities of sorghum beer residue (SBR) have been evaluated in the diets of chickens with some success (Demeke,2007 and Pousga et al 2007), it's maximum utilization as a plant protein source have been limited by its high fibre content (Aduku, 1993). The fibre fraction of a feedstuff has the greatest influence on its digestibility. The need to further recycle SBR through the process of fermentation in order to reduce its fibre content, obtain a high protein biomass and interesting amino acid composition becomes eminent. Protein quality is measured by the type of amino acids present. There are twenty different types of amino acids, eleven of which are essential in poultry nutrition because they are not manufactured by the animal's body. These include Lysine, Leucine, Isoleucine, Methionine Phenylalanine, Threonine, Tryptophan , valine, Arginine, Histidine and Glycine (Anhwange et al., 2004). Dietary protein with all the essential amino acids in the proportion required by the animal is said to be a high quality protein. In this study, sorghum beer residue was supplemented with urea and methionine and fermented for 4-days and its amino acids composition compared with those of FAO protein standard and Animal Feed standard.

\section{MATERIALS ANDMETHODS}

\subsection{Sample collection and Inoculumpreparation.}

The sorghum beer residue was obtained from the local gin ("Burukutu") producers within Kaduna metropolis, Nigeria. Rumen content of cow was collected fresh just after slaughter at the Sabon-Tasha abattoir, Kaduna. This was then mixed with water in a 2:1 ratio on a weight by weight (w/w) basis and filtered through a mosquito net of pore size $2.78 \mathrm{~mm}^{2}$ (Ndams et al., 2011). The residue was discarded and the filtrate used as inoculum.

\section{$2.2 \quad$ Substrateinoculation}

The inoculation of sorghum beer residue prior to fermentation was carried out as described by Ndams et al. (2011). SBR was moistened with water at a ratio of $1: 5(\mathrm{w} / \mathrm{w})$. SBR was supplemented with urea and methionine concentrations at a ratio of $1.5: 0.37 \%$ (Fazaeli et al., 2007). The quantities of urea and methionine were first dissolved in the water containing the inoculum before wetting the substrate (SBR).

\section{$2.3 \quad$ Substrateinoculation}

On quantitative measurement, $2.67 \mathrm{~kg}$ of methionine and $10.80 \mathrm{~kg}$ of urea were dissolved in $3600 \mathrm{~kg}$ of water in which $72.00 \mathrm{~kg}$ of rumen liquor has been introduced before wetting $720 \mathrm{~kg}$ (twelve bags of $60 \mathrm{~kg}$ each) of SBR. The SBR was inoculated on concrete floor and then turned into a $5 \mathrm{ft}$ deep pit lined with polythene materials. It was properly compacted by feet to maintain perfect anaerobic condition. The urea and methionine supplemented SBR was allowed to ferment for 4days. After fermentation, the pit was opened, and the fermented material removed. The fermented product (RSBR) was sundried for 7days on concrete floor and samples taken for determination of amino acidscomposition.

\subsection{Determination of amino acidscomposition}

The determination of amino acids profile in SBR, RSBR and GNC samples were carried out at the Department of Zoology, University of Jos using methods described by Sparkman et al. (1958).

\section{RESULTS}

The amino acids profile of RSBR sample revealed the 
availability of all essential amino acids except tryptophan (alanine, arginine, glycine, histidine, isoleucine, leucine, lysine, methionine, phenylalanine, threonine and valine) in the samples.

Table 1 and figure 1 shows the amino acids profile of SBR, RSBR, GNC and other animal feed protein standards. The amino acids profile of the protein biomass (RSBR) produced after 4days fermentation, except for arginine, glycine and valine which were lower, all other essential amino acid concentrations were higher in RSBR than those of GNC. The amino acid concentrations of RSBR was numerically higher than those of Soya bean and FAO standards (with the exception of lysine which was lower compared to both) as well as that of Animal Feed Standard. Moreover, it had a superior profile in amino acid concentrations when compared to plantproteins.

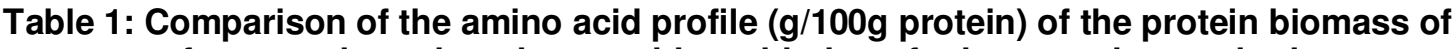
re-fermented sorghum beer residue with that of other protein standards

\begin{tabular}{lccrccc}
\hline Amino acid & SBR & ${ }^{*}$ RSBR & GNC & OFAO $^{\mathrm{a}}$ & $(\mathrm{SBC})^{\mathrm{b}}$ & ${\text { Animal feed standard }(\mathrm{AFS})^{\mathrm{c}}}$ \\
\hline Alanine & 8.66 & 8.89 & 2.10 & - & - & - \\
Arginine & 4.66 & 5.18 & 6.35 & - & 8.3 & - \\
Cysteine & 2.18 & 2.38 & 2.1 & 2.0 & 1.0 & 0.74 \\
Glycine & 3.17 & 3.60 & 7.8 & - & 4.5 & 2.43 \\
Histidine & 2.40 & 2.9 & 2.8 & - & 3.0 & - \\
Isoleucine & 4.18 & 4.63 & 2.1 & 4.20 & 5.6 & 2.57 \\
Leucine & 13.17 & 14.31 & 9.9 & 4.80 & 8.2 & 3.80 \\
Lysine & 2.38 & 3.02 & 2.1 & 4.20 & 6.8 & 3.20 \\
Methionine & 1.93 & 2.19 & 0.49 & 2.20 & 1.4 & 0.72 \\
Phenylalanine & 5.15 & 5.48 & 4.3 & 2.80 & 4.9 & 2.20 \\
Threonine & 3.48 & 4.53 & 4.3 & 2.80 & 4.0 & 1.97 \\
Tyrosine & 4.13 & 4.44 & 1.4 & - & 4.2 & - \\
Serine & 4.56 & 4.99 & 7.8 & - & - & - \\
Valine & 5.27 & 5.62 & 10.0 & 4.20 & 5.50 & 2.70 \\
\hline
\end{tabular}

øFood and Agricultural Organization

*Urea and methionine treated and fermented sorghum beer residue, GNC= Groundnut cake, SBC = Soy bean cake. Sources: $a=$ Araujo D'Souza (1986), b = Adapted from Park et al., 2002 (1991), $c=$ Lo and Morean (1986). RSB = Unfermented sorghum beer residue. 


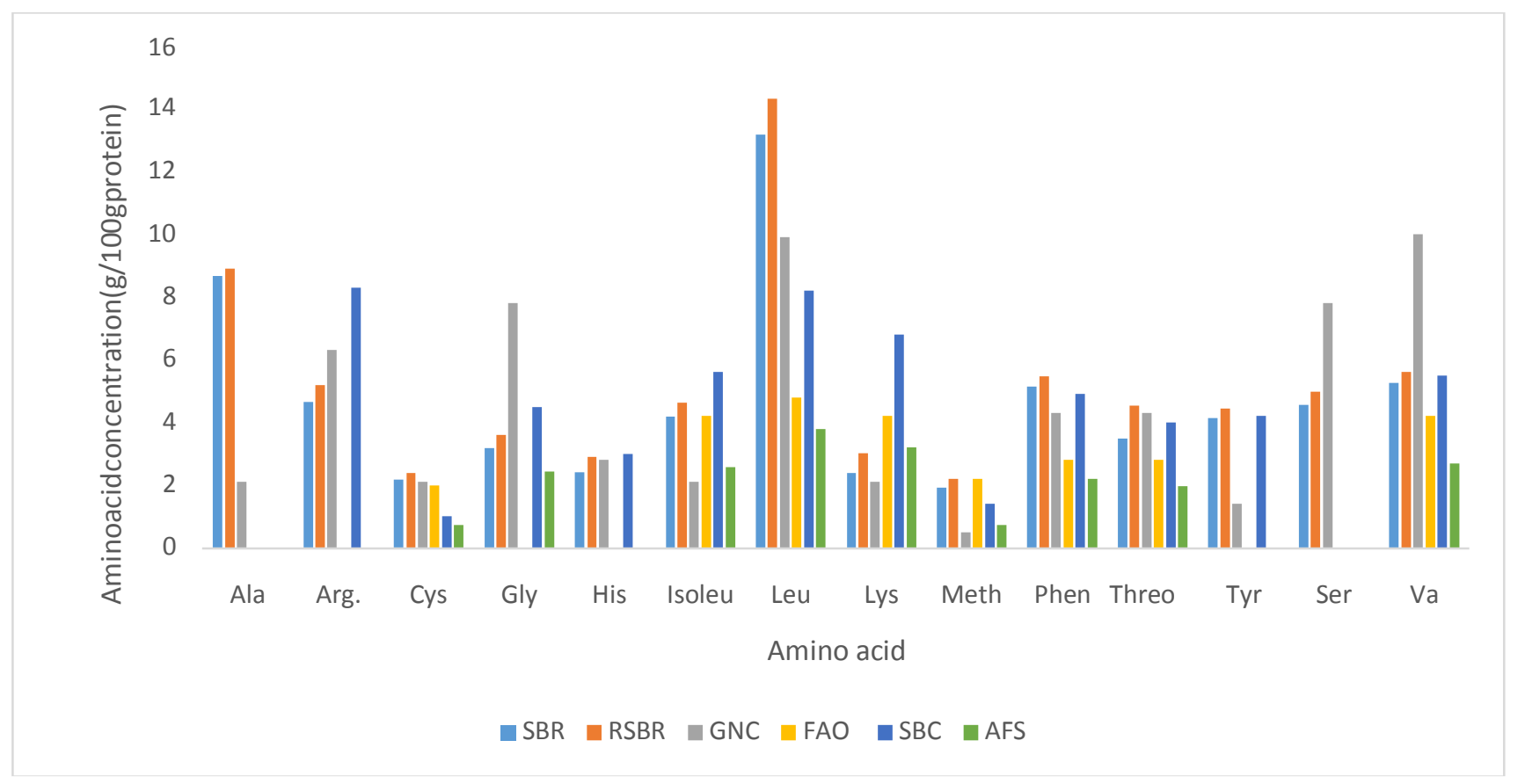

Figure 1: Comparison of the amino acid profile ( $\mathrm{g} / 100 \mathrm{~g}$ protein) of the protein biomass produced (RSBR) with other protein standard

\section{DISCUSSION}

The availability of essential amino acids in SBR and RSBR is an indication that RSBR can serve as protein sources in non-ruminant nutrition (McDonald et al., 1998). The amino acid content of all the essential amino acids of RSBR samples were numerically higher compared to the unfermented (SBR) sample in this study. This is not in agreement with Spear et al., (1978) who observed numerical decrease in essential amino acids in lambs fed tall fescue supplemented with I-methionine Sulphur at 0.05 and $0.15 \%$ compared to the control $(0 \%)$.

The amino acid profile of the protein biomass (RSBR) produced in this study, was observed to be higher numerically than those of GNC. It was also superior to the amino acid profile of other plant proteins. The quality of the RSBR protein produced was equal or greater than that of the conventional ingredients in terms of its amino acid profile and the standard set for animal feed. This revealed that RSBR has all the essential amino acids for animal feed. This is in agreement with Ofuya and Obilor (1993) who observed that Rhizopus fermented cassava peel feedstuff contained all the essential amino acids that were far more digestible than the control. Also Almeida et al. (1995) observed that the protein obtained $(34 \%$ of the biomass) contained all the essential amino acids for animal feeds when eucalyptus hydrolyzate was fermented using paecilomycestes variottii (fungus).

When compared to the FAO and soya bean standards, one can see that the protein standards and the protein biomass produced after 4days fermentation of
SBR with urea and methionine supplementation contains all the essential amino acids for animal feeds. Moreover, it has a superior amino acid profile when compared to other plant proteins.

\section{CONCLUSION}

In conclusion, the results of this study indicates that 4days fermentation of sorghum beer residue supplemented with urea and methionine resulted in a protein biomass (RSBR) with superior amino acid profile compared to GNC, Soyabean cake, FAO and Animal Feed Standards and can be used as an alternative to conventional feed ingredients in animal feed.

\section{AUTHORS' CONTRIBUTIONS}

- The authors after the study was proposed to them participated in the conception and design of thestudy.

- Assistance was also received in the area of data graphical interpretation and in the editing of the manuscript for publishing

\section{ACKNOWLEDGEMENT}

The amino acid profiles determination of SBR, RSBR and GNC carried out at the Department of Zoology, University of Jos, Nigeria by Dr Titus Ojobe is 
gratefullyacknowledged.

\section{REFERENCES}

Aduku, A. O. (1993). Tropical feedstuffs Analysis Table. FacultyofAgriculture,

Almeida e Silva, J.S. Ismeal, J.B. Maria, M.M. and Magdala, A.T. (1995). Microbial protein production by Paecilomyces variotii cultivated in eucalyptus hemicellulosic hydrolysate. Bioresource Technol. 52:197-200.

Anhwange, B.A, Ajibo, V.O. and Oniye, S.J (2004). Amino acid composition of seeds of Moringa oleifera (Lam), Detarium microcarpum (Guill \& Sperr) and Bauhinia monandra (Linn). ChemClass I. (2): 9-13.

Araujo, A. and D'Souza, J. (1986). Enzymatic saccharification ofpretreated rice straw and biomass production.

Biotechnol. and Bioengng. 28, 15039.

Demeke, S. (2007). Comparative nutritive value of Atella and industrial brewers grains in chicken starter ration in Ethiopia. Livestock Research for Rural Development. 19 (1), http://www.cipav.Org.co/Irrd19/1/deme19008.htm

Fazaeli, H., Mashsyekhi, M. R. and Mansouri, H. (2007). Effect of Nitrogen-Sulfur ratio on the digestibility of roughage based diet incubated with rumen liquor of buffalo. Ital. J. Anim. Sci.6, (2): 450-45.

Lo, S. N. and Moreau, J. R. (1986). Mixed culture microbial protein from waste sulfite pulping liquor II. Its production on pilot plant scale and use in animal feed. Can. J. Chem. Engng. 64,639- 46.

Madubuike, F. N. and Ekenyem, B.U. (2006).
Haematology and serum biochemistry Characteristics of broiler chicks fed varying dietary levels of ipoemea asarifolia leaf meal. Int. J. Poult. Sci. 5(1):09-12.

McDonald P., Edwards, R.A., Greenhalg, J.F.D. and Morgan, C.A. (1998). Animal Nutrition (5thed). London Longman GRP. Ltd. Pp.623.

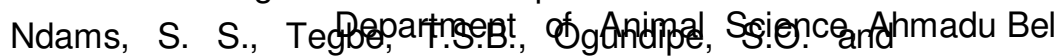
Sheyin, Z. (2011). Determination of the optimum inoculums concentration and fermentation period and their effect on nutrient composition of Brewers dried grains. Sci. World J.6 (1): 13-19.

Ofuya, C.O. and Obilor S.N. (1993): The suitability of fermented cassava peel as a poultry feedstuff. Bioresources Technol. 44:101-104.

Park, H.Y., Kim, H.K., Kim, H.S., Lee, H.S., Shin, I.S. and Whang, K.Y (2002). Effects of the different

Soybean Meal Sources on Layer and Broiler Performance. Asian-Aust. J. Anim. Sci 2002. Vol.15, no.2:254-265.

Pousga, S., Boly, H., Lindberg, J.E. and Ogle, B. (2007). Evaluation of Traditional Sorghum Beer Residue, Shea-Nut (Vitellaria paradoxa) Cake and Cottonseed (Gossypium Spp) Cake for Poultry in Burkina Faso: Availability and Amino Acid Digestibility. Int. J. Poult. Sci. 6(9): 666-672.

Sparkman, D.H., Stein, E.H. and Moore, S. (1958). Antinutritive recording apparatus for use in the chromatography of amino acid analytical chemistry.30:1190-1191.

Spear, J. W., Ely, D. G. and Bush, L.P. (1978). Influenced of supplemental sulfur on in vitro and in Vivo Microbial Fermentation of Kentucky 31 Tall Fescue. J. Anim.Sci. 47: 552-560. 